University of Texas Rio Grande Valley

ScholarWorks @ UTRGV

Psychological Science Faculty Publications and

Presentations

$11-2020$

\title{
Service encounters across the lifespan in individuals with autism spectrum disorders: Results from a multisite study in Latin America
}

\author{
Cecilia Montiel-Nava \\ The University of Texas Rio Grande Valley \\ Sebastián Cukier \\ Gabriela Garrido \\ Daniel Valdez \\ Cristiane Paula
}

See next page for additional authors

Follow this and additional works at: https://scholarworks.utrgv.edu/psy_fac

Part of the Child Psychology Commons

\section{Recommended Citation}

Montiel-Nava, C., Cukier, S., Garrido, G., Valdez, D., Paula, C. S., García, R., Rosoli, A., Irarrázaval, M., \& Rattazzi, A. (2020). Service encounters across the lifespan in individuals with autism spectrum disorders: Results from a multisite study in Latin America. Research in Autism Spectrum Disorders, 79, 101670. https://doi.org/10.1016/j.rasd.2020.101670

This Article is brought to you for free and open access by the College of Liberal Arts at ScholarWorks @ UTRGV. It has been accepted for inclusion in Psychological Science Faculty Publications and Presentations by an authorized administrator of ScholarWorks @ UTRGV. For more information, please contact justin.white@utrgv.edu, william.flores01@utrgv.edu. 


\section{Authors}

Cecilia Montiel-Nava, Sebastián Cukier, Gabriela Garrido, Daniel Valdez, Cristiane Paula, Ricardo García, Analía Rosoli, Matías Irarrázaval, and Alexia Rattazzi 
TITLE: Service Encounters Across the Lifespan in Individuals with Autism Spectrum Disorders:Results from a Multisite Study in Latin America

Cecilia Montiel-Nava ${ }^{\mathrm{a}}$, Sebastián Cukier ${ }^{\mathrm{b}}$ Gabriela Garrido ${ }^{\mathrm{c}}$, Daniel Valdez ${ }^{\mathrm{d}}$, Cristiane Paula ${ }^{\mathrm{e}}$, Ricardo García ${ }^{\mathrm{f}}$, Analía Rosolì, Matías Irarrázaval ${ }^{\mathrm{h}}$, Alexia Rattazzib

\section{Cecilia Montiel-Nava}

${ }^{a}$ Department of Psychological Sciences, Universidad de Texas Rio Grande Valley, Edinburg, TX. Department of Psychological Science. University of Texas Rio Grande Valley. $1201 \mathrm{~W}$ University Dr, Edinburg, TX 78539 EIEAB 3231 ceciliamontiel@utrgv.edu

\section{Sebastián Cukier}

${ }^{\mathrm{b}}$ PANAACEA (Programa Argentino para Niños, Adolescentes y Adultos con Condiciones del Espectro Autista). Domingo Repetto 1145, B1640EMQ Martínez, Buenos Aires, Argentina. sebastiancukier@panaacea.org

\section{Gabriela Garrido}

c Universidad de la República, Montevideo, Uruguay.

Bulevar General Artigas 1550, 11600 Montevideo, Departamento de Montevideo, Uruguay gabrielagarridof86@gmail.com

\section{Daniel Valdez}

${ }^{\mathrm{d}}$ FLACSO and Universidad de Buenos Aires, Argentina.

Tucumán 1966, C1050AAN CABA, Argentina 
daniel.valdez@me.com

\section{Cristiane Paula}

eDevelopmental Disorder Program, Mackenzie Presbyterian University, Sao Paulo, Brazil.

Rua da Consolação, 930Consolação, São Paulo, SP, 01302-907

csilvestrep09@gmail.com

\section{Ricardo García}

fUniversidad de Chile, Santiago, Chile.

Av. Libertador Bernardo O'Higgins 1058, Santiago de Chile, Chile

ricardo.garcia.sepulveda@gmail.com

\section{Analía Rosoli}

g Organización Estados Iberoamericanos para la Educación, la Ciencia y la Cultura (OEI), Santo Domingo, Dominican Republic.

Av. Sarasota No. 20, Torre AIRD, Santo Domingo

analiarosolimurillo@gmail.com

\section{Matías Irarrázaval}

hMillenium Institute for Research in Depression and Personality, Santiago, Chile.

Avda. Vicuña Mackenna 4860, Macul, Santiago, Chile

matias.irarrazaval@minsal.cl 


\section{Alexia Rattazzi}

bPANAACEA (Programa Argentino para Niños, Adolescentes y Adultos con Condiciones del Espectro Autista). Domingo Repetto 1145, B1640EMQ Martínez, Buenos Aires, Argentina. alexiapanaacea@gmail.com

Correspondence concerning this article should be addressed to Cecilia Montiel-Nava. Department of Psychological Science. University of Texas Rio Grande Valley. 1201 W University Dr, Edinburg, TX 78539 EIEAB 3231- (956) 665-7950 ceciliamontiel@utrgv.edu 
- Cecilia Montiel-Nava Conceptualization, Methodology, Formal analysis, Investigation, Writing - Original Draft, Writing - Review \& Editing

- Sebastián Cukier Conceptualization, Methodology, Investigation, Writing Review \& Editing

- Gabriela Garrido Conceptualization, Methodology, Investigation, Writing Review \& Editing

- Daniel Valdez Conceptualization, Methodology, Investigation, Writing Review \& Editing

- Cristiane Paula Conceptualization, Methodology, Investigation, Writing Review \& Editing

- Ricardo García Conceptualization, Methodology, Investigation, Writing Review \& Editing

- Analía Rosoli Conceptualization, Methodology, Investigation, Writing Review \& Editing

- Matías Irarrázaval Formal analysis,

- Alexia Rattazzi Conceptualization, Methodology, Investigation, Project administration, Writing - Review \& Editing 


\section{Background}

Core symptoms of Autism Spectrum Disorder (ASD) continue to affect everyday life as children grow and transition into adulthood. That way, different services may be needed at various stages of their lifetimes. This study aimed to describe service encounters and hours of service per week for individuals with ASD in Latin American countries and compare the data from three age groups (preschoolers, school-aged, and adolescents).

\section{Methods:}

The data were obtained from an online survey adapted by Red Espectro Autista Latinoamerica (REAL) in 6 different countries in South \& Central America. The total sample was composed of 2520 caregivers of children and adolescents with ASD.

\section{Results:}

Services encounters for Speech, Occupational and Behavioral Therapies decreased with patient age, while medication increased. Regardless of the age group, a large proportion of individuals (19-37\%) were not receiving treatment, and those receiving treatment got fewer hours than best practice recommendations. For adolescents, the gaps in treatment are even greater and less consistent.

\section{Discussion}

Failure to offer timely identification and intervention for ASD will result in more impairment of the individual and burden for the family. Although there are several initiatives to develop more resources for this population in Latin-America, the provision of services for ASD is still undervalued. Many such individuals might not be receiving the services they need, while most children are mainly receiving therapies with low to moderate evidence at a frequency below the recommended standards. 


\section{Highlights}

- Core symptoms of ASD continue to affect everyday life as children grow

- The most commonly endorsed services are not specific to ASD and have low to medium evidence

- Regardless of the age group, a large proportion of individuals are not receiving treatment, and those receiving treatment get fewer hours than best practice recommendations. 
Service Encounters Across the Lifespan in Individuals with Autism Spectrum Disorders: Results from a Multisite Study in Latin America

Developmental disabilities, including autism spectrum disorders (ASD), profoundly affect children's health and functioning. Individuals with ASD might have a higher level of service needs than other groups of individuals with developmental (Vohra et al., 2014) .Core symptoms of ASD continue to affect everyday life as children grow and transition into adulthood, so that different services may be needed at various life stages (Civad et al., 2013). For example, young children require access to early assessment and early intervention services (Howlin et al., 2009), whereas school-age children need behavior management and school support services (Lai \& Weiss, 2017). For adolescents with ASD, complex clinical needs and the presence of other mental health problems (Gotham et al., 2015) will warrant different types of services (Shattuck et al., 2011)

Symptoms, ASD severity, and the lifelong nature of the condition complicate service planning to address needs and care at various life stages (Moes \& Frea, 2002; Stahmer et al., 2011). Few studies have explored the variation in service use in different developmental stages (Kennedy-Hendricks et al., 2018; Rast et al., 2018; Turcotte et al., 2016). The financial burden of ASD on health, education, and social services is higher than that of other childhood conditions such as diabetes, asthma, or intellectual disabilities (Knapp et al., 2009). It has been estimated that worldwide there are 1.3 million children and adolescents between the ages of 3 and 19 years with ASD (Nightingale, 2012). The large and rapidly growing population of adolescents with ASD makes it imperative to identify the services needed for these populations (Turcotte et al., 2016). Furthermore, the dearth of research about these variables shows the importance of studying and comparing the use of services across the lifespan and examining the changes in the 
needs of the patients over time. Previous research has rarely examined the use of specific services in the different age groups (Cidav et al., 2013). On the contrary, researchers often consider one category of "services" in which they combine various mental health interventions, hindering understanding of how different services are accessed in different developmental stages.

The limited research in the use of services by individuals with ASD across their lifetimes complicates the understanding of whether individuals with ASD do not receive services because what they need is not available or because they require different or more services. Health disparities have been related to the uneven distribution of social, economic, political, and environmental resources (Rubin et al., 2011). In particular, inadequate access to health care and educational inequalities is common to low- and middle-income countries (LAMICs) (Durkin et al., 2015).

Although the prevalence and clinical presentation of ASD are similar regardless of race or ethnicity (Fombonne, 2009; Nowell et al., 2015), racial disparities affect the rates of identification and diagnosis, the access and use of services, and the presence of stigma in different geographical areas around the globe and across different races or ethnicities as well as socioeconomic status levels (Magana et al., 2013; Mandell et al., 2009; Montiel-Nava et al., 2017). The Latino ethnicity has also been associated with more health care access problems, poorer quality of care, and less service use (Broder-Fingert et al., 2013; Lindly et al., 2019; Magana et al., 2013). Systemic factors such as lack of resources in rural areas, insurance type, and education level have been predictive of a reduced delivery of therapeutic support services such as speech and occupational therapies and behavioral management (Lindly et al., 2019; Thomas et al., 2007). 
To understand the challenges caregivers of children with ASD living in Latin America face, it is crucial to understand their context, culture, and limitations beyond what is attributable to the condition itself. For this study, we will be presenting data from Argentina, Brazil, Chile, the Dominican Republic, Uruguay, and Venezuela. These are all Latin American countries that share the cultural heritage from Spain and Portugal mixed with aboriginal and African cultures. We share music, food, and family values ([familism] (Padilla et al., 2020). Nonetheless, health inequalities are widespread for poor and vulnerable populations ([i.e., women, children, adolescents, and indigenous or aboriginal people];(UNICEF, 2016; World Bank, 2015). As shown in Table 1, the World Bank (2017) classifies these six countries as upper-middle or high income. All have a gross domestic product (GDP) above the 50th percentile of all world countries (World Bank, 2017);(International Monetary Fund, 2020). However, the mental health expenditure per person, as well as the number of mental health professionals, is below standard (World Health Organization [WHO], 2017). People in these countries hardly ever have access to services and trained specialists. Of the participating countries, Argentina is the only one with a solid legal framework to protect individuals with autism, including a law that covers most health services for people with disabilities ((Argentine Ministry of Health and Social Development, 1997, 2019)Argentine Ministry of Health and Social Development, 1997, 2019), a law for autism (Argentine Ministry of Health and Social Development, 2014(Argentine Ministry of Health and Social Development, 2001, 2014)), and a unified disability certificate allowing access to clinical and educational services (Argentine Ministry of Health and Social Development, 2001). Chile (Ministry of Health, 2011) and Brazil ((Brazilian Ministry of Health, 2014b; Brazilian Ministry of Health, 2014a)Brazilian Ministry of Health, 2014a; 2014b) recognized ASD as a disability in 2012 and 2010. Since 2008, Chile has published a guide for teachers ((Chilean División 
Educación General, n.d; Chilean Ministry of Health, 2011)) and a guideline for detecting ASD (Chilean Ministry of Health, 2011). The other countries have only promulgated laws that ratify the rights protected by the Convention on the Rights of Persons with Disabilities (CRPD) without articulating these rights in the context of the country's health or educational system (Table 1). Except for Uruguay, which has a 20\% copayment, the rest of the countries report universal health coverage for mental health services ((World Health Organization, 2005)WHO, $2005,2017)$. Nonetheless, this universal health coverage is administered in overbooked facilities with few trained professionals and long waiting lists (De Almeida et al., 2005; Kohn et al., 2005; Saldivia et al., 2004). In practice, all these supposedly high-income countries are low- and middle-income countries, and their people's priorities are dealing with poverty, inequality, and personal safety. For example, in the past decade, Venezuela has been afflicted with the worst inflation in the world (2297\%), while Argentina occupies fifth place (42.1\%), and Uruguay 20th ([11.05\%](International Monetary Fund, 2020). To diminish health inequalities in countries with these political and economic circumstances and with a growing ASD prevalence, reliable data, solid evidence, and sound knowledge must replace obscurantism, regressive ideology, and inefficiency in the decision-making process (UNICEF, 2016). This approach applies to all health-related issues, including developmental disabilities such as ASD.

Amid the low government investment in mental health in general, several participating countries have developed guidelines, epidemiological data, and validation studies for identifying, diagnosing, and treating children with ASD. Brazil (Paula et al., 2011) and Venezuela (MontielNava \& Pena, 2008) have made estimates of the prevalence of ASD; however, these were solitary attempts to raise epidemiological data to inform policymakers about the needs of the growing population with ASD in those countries. In some countries, validation of several 
screening and diagnostic questionnaires has been conducted (Backes, 2014; Becker et al., 2012;

Coelho-Medeiros et al., 2019; Cukier, 2019; Galdino et al., 2020; Manzone, 2013; Pacifico et al., 2019; Paula et al., 2018; Pereira et al., 2008; Soto et al., 2015; Stewart \& Lee, 2017). As for interventions, some countries have developed research projects related to parent-mediated interventions (Bagaiolo et al., 2017; Bordini et al., 2020). ASD awareness, identification, and services in Latin American countries have been growing in the past decade.

The objective of this study was to describe the types of service encounters and hours of service per week for each endorsed service encounter for individuals with ASD in Latin American countries and to compare the data from three age groups (preschoolers, elementaryschool-aged, and adolescents). This study is unique in describing the data of the families affected by ASD from a group of different countries in Central and South America with comparison across lifespans.

\section{Methods}

The data were obtained from an online survey adapted by Red Espectro Autista Latinoamerica (REAL; Latin American Autism Spectrum Network). REAL was created to study the needs of people with ASD living in Latin American countries. The First Latin American ASD Conference took place in Chile in 2013. At that moment, Argentina, Chile, and Brazil signed the Santiago Declaration, an agreement to establish a Latin American network to improve ASD awareness, legislation, education, and research capabilities in the region (Varios, 2013). After that meeting, other countries with active researchers in the ASD field were invited to participate in the network and adhere to the declaration. By May 2015, the Dominican Republic, Uruguay, and Venezuela had accepted the invitation and joined the network. This multisite study 
was carried out in those six countries (Argentina, Brazil, Chile, the Dominican Republic, Uruguay, and Venezuela).

\section{Sample}

The study was advertised through social networking platforms, parent and professional associations, and institutions that provide services for individuals with ASD. A convenience sample was drawn from each country because no population-based sampling frame of children with ASD and their families exists in the selected countries. For recruitment, REAL advertised the study through social networking, parental and professional associations (e.g., psychological associations, pediatrics associations), and institutions that provide services for individuals with ASD in each participating country. The survey was to be completed on a web form; to do so, caregivers needed to have a fifth-grade literacy level and access to a computer and the internet.

Of the participants, 2,965 caregivers completed the survey. Data sets were reviewed for duplicate or missing cases, which were excluded from the analysis. Duplicates were verified by comparing initials used in the consent form, country and region of residence indicated in the survey, and the caregivers' IP addresses. The response options for the question on diagnosis were based on the different diagnostic measures used for DSM-IV (American Psychiatric Association [APA], 2000) and DSM-5 (APA, 2013) because those are the coding systems used by the participant countries: autism/autistic disorder, Asperger's disorder, pervasive developmental disorders (PDD), pervasive developmental disorders — not otherwise specified (PDD-NOS), autism spectrum disorders (ASD), and other (referring to non-ASD diagnoses). Eleven cases were "empty" entries (recorded for the system as a completed survey but only complete regarding the country information); 108 reported a diagnosis under the "other" category; and 29 did not complete the question on diagnosis. This category included a space to write other 
diagnoses and cases that reported something different than ASD (e.g., communication disorders, intellectual capacity). However, we retained cases that had selected the "other" option but in the provided space included a separate diagnosis or genetic disorder in addition to ASD. For this paper, participants older than 18 years of age were excluded $(n=297)$ because of the heterogeneity of the ages within this group (18-63). The total number of excluded cases constituted $15 \%$ of the initial sample $(n=445)$. Those entries were excluded from the analysis, yielding a final sample of 2,520 caregivers. The total sample was composed of $1,008(40 \%)$ in the preschool group ( $<6$ years old at the time of the survey); 1,217 (48.3\%) in the school-age group (7-12 years old); and 295 (11.7\%) in the adolescent group (13-17 years old).

\section{Instrument}

Daniels and the Southeast European Autism Network (SEAN) developed the Caregiver Needs Survey to assess the needs of families affected by ASD (Daniels et al., 2017; PejovicMilovancevic et al., 2018) The survey contained four sections: family demographics; affected individual characteristics; service encounters; and parent/caregiver perceptions, including stigma. Some questions and responses were adapted from existing surveys on children with special health care needs. Those surveys included the Child with ASD Questionnaire, Version 2.0.3 (Interactive Autism Network [IAN], 2016); the Survey of Treatment as Usual, COST Network (Salomone et al., 2016); Survey of Pathways to Diagnosis and Services (Centers for Disease Control and Prevention [CDC], 2015); the National Survey of Children with Special Healthcare Needs (CDC, 2014); the Affective Subscale, from the Affiliate Stigma Scale (Mak \& Cheung, 2008); and the Family Quality of Life Survey (Hoffman et al., 2006). 
Questions for the section on service encounters included past and current service use for a variety of ASD-specific and non-ASD-specific services as well as education and educational supports (adapted from the Survey of Pathways to Diagnosis and Services; CDC, 2015)

For the present study, the survey was translated into both Spanish and Portuguese; a third party then translated it back to English (original language) to ensure the integrity of the instrument was preserved in translation. After this process was complete, each country made modifications to items related to educational modalities and levels, insurance coverage types, and informed consent details to ensure validity for cultural contexts. For example, names for the different school systems, mainstream classes, special education schools, and educational aids varied across countries. Insurance coverage was one of the main changes because of the heterogeneity of government involvement among countries. In general, language adjustments were responsible for most changes and adaptations to the survey.

After the final version was established, the survey was uploaded to a server for online access. Each country team ran a pilot of the version, with 10 families per country, to study caregivers' reaction to the instrument in terms of length, the language used, appropriateness and lay readability, and the website's accessibility. No modifications were needed at this stage. For each country, the national coordinator oversaw survey implementation and obtained clearance from an accredited ethical review board. The REAL secretariat provided technical support for website management. Only national coordinators had access to the database.

Upon entering the website, caregivers were first asked to choose the country of residence from a cascade menu. This selection took them to the informed consent for that particular country, and caregivers needed to provide their initials as a signature. After informed consent was given, a random computer-generated identification (ID) number was provided. The ID 
offered caregivers the opportunity to return any time to complete the survey without losing data they had already entered. The survey was anonymous, and no personal information (e.g., name, phone number, email address) was required. The data entered were transferred to an Excel worksheet that only the national coordinator could access. Ethical approval was granted by the ethics board of the different agencies with which the national coordinators were affiliated. Dr. Rattazzi was the national coordinator for Argentina (PANAACEA), Dr. Paula for Brazil (Mackenzie Presbyterian University and Federal University of São Paulo), Dr. Garcia for Chile (University of Chile), Dr. Rosoli for the Dominican Republic (Organization of Ibero-American States for Education, Science and Culture), Dr. Garrido for Uruguay (University of the Republic), and Dr. Montiel-Nava for Venezuela (University of Zulia).

\section{Data Analysis}

At the end of data collection (April 2016), the data were coded, cleaned, and merged into a single data set with all countries included. The original data set used for data collection was an Excel worksheet exported to Statistical Package for the Social Sciences (SPSS) - Version 26 for analysis. Age groups were chosen based on transition points in the school system. Data analysis included calculations of central tendency and frequency. Correlations between age group and hours of service were calculated using $x^{2}$ or Spearman's $p$ correlation. Country, sex of the individual with ASD, another family member with ASD, insurance type, current diagnosis, disruptive behaviors, and professional involved in the first diagnosis were treated as nominal; age of diagnosis, severity index, and the caregiver's highest level of education were treated as ordinal. Group comparisons (based on age groups) were conducted using chi-squared tests for categorical variables and analysis of variance (ANOVA) for continuous variables. 
The main dependent variable was the proportion of the services and hours of services that individuals had received during their lifetime and/or currently (services encounters). Participants indicated (1) previous services encounters from a list of 10 services, (2) current service encounters from a list of 10 services, and (3) number of hours per week for each current service at the time of the study. The list of services included medication, physical therapy/physiotherapy (PT), behavior therapy (BT)/behavior modification, occupational therapy (OT), cognitive rehabilitation (CR), psychodynamic therapy, speech therapy (ST), biomedical intervention, and sensory integration therapy. Participants selected services from the same list in both questions. Participants also indicated (4) current school enrollment (regular public or private school, special education school, home schooling, not enrolled in school) and (5) any additional academic service at school (special education classrooms for children with disabilities, special classrooms for children with ASD, school tutors).

In addition to age groups, independent variables included sociodemographic measures, clinical variables, and severity index. Information came from the survey's responses. The caregiver completed all items in reference to the person with ASD. The sociodemographic measures included sex of the individual with ASD, highest level of education attained by the primary caregiver, insurance coverage (private, public, or both), and country. Clinical variables referred to the diagnosis of the affected individual (autism/autistic disorder, Asperger's disorder, PDD, PDD-NOS, ASD, and other), the type of professional involved in the first diagnosis (psychiatrist, interdisciplinary team, neurologist, developmental pediatrician, psychologist, pediatrician, nurse, and primary care doctor), and the presence of disruptive behaviors at the time of the study. The severity index was a composite score developed to obtain a comparable measure of verbal and intellectual development and functioning level scores. The relationship 
between language development, intellectual disability, and level of functioning was assessed through three different questions in the survey. To achieve comparability across subjects, the scores were transformed to severity scores combining the three variables.

\section{Results}

\section{Family Demographics}

The sample of 2,520 was $84.3 \%$ male with a mean age of 7.2 years $(\mathrm{SD}=3.8)$. Regarding country distribution, 39.7\% were from Brazil, $28.1 \%$ from Argentina, $12.7 \%$ from Uruguay, $10 \%$ from Chile, 5.2\% from the Dominican Republic, and 4.9\% from Venezuela. Most children in all countries were elementary school aged, followed by preschool aged and adolescent. The only exception was Brazil, with more preschool-aged children in their sample $(\mathrm{p}=0.001)$. The mean age of diagnosis was 29.9 months, and there were statistically significant differences among age groups $(\mathrm{F}=283.4, \mathrm{p}=0.001)$. Preschool-aged children were diagnosed at an earlier age $(32.8$ mos.) than school-aged children (50.9 mos.), and school-aged children were diagnosed earlier than adolescents (73.1 mos.). Most caregivers (58.32\%) had an undergraduate degree, and 74.2\% used only private insurance to cover costs associated with the family member with ASD. Of the participants, $11.3 \%$ had another member in the family with ASD, more frequently in the schoolaged group $(\mathrm{p}=007$; Table 2$)$

The most prevalent diagnosis among the sample was ASD (47\%), followed by Autism/Autistic Disorder (16.4\%), Asperger Disorder (15.1\%), PDD-NOS (12.5\%), and PDD (9\%). For pre-school (59.5\%) and school-age (41.5\%) groups, ASD was the most frequent 
diagnosis, whereas for the adolescent group Asperger Disorder (33.2\%) was the most frequent $(p=0.001) .($ Table 2$)$

The analysis of severity index scores shows a progression of severity as a function of age: preschool children showed less impairment than elementary school children, and elementary school children less than adolescents. For elementary school (\%) and adolescents (47.1\%), high severity was the most frequent report $(\mathrm{p}=0.001)$.

The distribution of professionals involved in first diagnosis also varied widely: $42.8 \%$ neurologists, $15.2 \%$ psychiatrists, $11.9 \%$ psychologists, and $5.4 \%$ pediatricians $(p=0.001)$. Although neurologists were the most frequently consulted professionals for all three groups, they were consulted most frequently for the preschool group (46.2\%). On the other hand, psychiatrists were consulted with more frequency for the adolescent group $(22.4 \%)$, whereas pediatricians $(5.4 \%)$ and developmental pediatricians $(4.5 \%)$ were the least consulted professionals for all age groups.

\section{Service Encounters}

Service encounters were calculated by asking caregivers if the affected family member received any of the services listed in the survey ever and/or currently, and the number of hours per week for each current service at the time of the study. For lifetime service encounters, 18.7\% $(n=469)$ of the sample had not received any kind of health services as listed in the survey, with the same proportion of children without lifetime service encounters for all three age groups. Most participants had received between one and six types of health services in their lifetime $(68.7 \%)$, and fewer participants had more than seven different types of health services $(12.6 \%)$ (Table 3). The top five lifetime services used across age groups were ST (65.5\%), OT (46.6\%), BT (40.2\%), medication (37.3\%), and PT (31.0\%). 
ST was the most frequently used service for all ages, with higher frequency for preschool (65.1) and elementary-school (62) groups than for adolescents (58.7) ( $\mathrm{p}=0.03)$. OT was in second place for the preschool (44.7\%) and school-age (48.5\%) groups but not for adolescents (45.7\%). BT was very frequent in all three groups, reaching third place for pre-school children (35.5\%), fourth place for school-age children (43.5\%), and fifth place for adolescents (42.5\%) ( $p=.003)$. For the whole sample, medication ranked fifth as type of service encounter and was more frequent for adolescents (53.3\%) and school age children (46.6\%) than for pre-school children $(21.4 \%)(p=0.001)$. The least used services caregivers reported were psychodynamic therapies $(17.8 \%)$ and biomedical treatments (14.7\%). The analysis of lifespan service encounters across the three different age groups showed that the use of medication $(\mathrm{p}=0.001), \mathrm{PT}(\mathrm{p}=0.001)$ and psychodynamic therapy $(\mathrm{p}=001)$ increased with age, whereas OT $(\mathrm{p}=0.04)$ and ST $(\mathrm{p}=0.014)$ decreased with age.

For current service encounters, the order of encounters by type is the same as lifetime encounters for speech, occupation and behavioral therapy and medication; although frequency of use is lower than lifetime use of the same services (Table 4). The fifth place is occupied by CR (19.3\%) instead of PT (18.4\%). As in lifetime service encounters, psychodynamic therapy $(12.2 \%)$ and biomedical treatment $(8.5 \%)$ are the least frequent service encounters for current measurements; they have also lower frequency than in lifetime use. For current service encounters, medication $(\mathrm{p}=0.001)$ and psychodynamic therapy $(\mathrm{p}=0.001)$ increased with age, whereas ST $(p=0.001)$, OT $(p=0.001)$ and sensory integration therapy $(p=0.001)$ decreased with age.

The survey also asked about current number of hours per week for each of the endorsed services. The average hours per week ranged from 5.21 hours for ST to 12.66 hours for 
psychodynamic therapy (Table 4); without the differences among age groups reaching statistical significance. However, for the analysis of total hours of all services per week, adolescents received fewer hours of services per week. In general, preschool children received an average of 4.21 hours of services per week, elementary school children 3.98 hours, and adolescents 3.38 hours. Moreover, 37\% ( $\mathrm{n}=939)$ of the sample were receiving zero hours of services per week, with this percentage increasing with age: $51 \%(\mathrm{n}=151)$ of adolescents were receiving no services at the time of the studies, compared with $32 \%(n=323)$ of preschool children and $38 \%(n=465)$ of elementary school children. Most children were receiving between 1 and 5 hours of services per week $(45 \%, \mathrm{n}=1120)$, also demonstrating a decrease in hours of services with age (Table 4).

Most children were enrolled in regular school (77.2\%), with the enrollment decreasing with age $(p=0.001)$. However, $16 \%$ of the sample was enrolled in in special education schools, and enrollment increased with age $(\mathrm{p}=0.001)$. Homeschooling was the least frequent educational placement $(0.5 \%)$ with no differences among age groups. $5.6 \%$ of children were not enrolled in school at the time of the study, with more children in the preschool (7.1\%) and adolescents $(9.9 \%)$ groups $(\mathrm{p}=0.001)$. (Table 5) $57.8 \%(\mathrm{n}=1133)$ of the sample were not receiving any type of educational services at the time of the survey. Comparison across age groups shows that $69.3 \%$ of children in the preschool group were receiving no educational services; $55.9 \%$ of the school-age children and $67.6 \%$ of adolescents were also without these services $(p=0.04)$. Special education classrooms were more prevalent among school age children $(\mathrm{p}=0.04)$; as were inclassroom tutor (shadow) $(25.4 \%)(\mathrm{p}=0.31)($ Table 5$)$.

There was no statistically significant association between sociodemographic and clinical variables and the hours of services received for any of the age groups (Table 6). 


\section{Discussion}

The reported prevalence of ASD has increased markedly around the world, including in LAMICs (Elsabbagh et al., 2015). Consequently, the demand for ASD-specific services (health and education) has risen and there is a need for an understanding of how those services are used across the lifespan. This study sought to investigate the service encounters and hours of services received by individuals with ASD in Latin American countries across different age groups. The sample with individuals from 1 to 17 years of age allows for a comparison of type of services encounters as well as hours of services per week in the different age groups.

As expected, males were more prevalent than females in all age groups at a 5:1 ratio for the total sample (Elsabbagh et al., 2012; Loomes et al., 2017; Mandy et al., 2018). ASD was the most prevalent diagnosis for the whole sample except for adolescents, for whom Asperger's syndrome was the most frequent diagnosis. Forty percent of our sample was younger than six years old, and it is most likely that when they were diagnosed, DSM-5 criteria were in effect (APA, 2013). Our sample was highly educated (81\% with an undergraduate degree or higher): adolescents had caregivers with the highest educational background, which might be related to the nature of the sampling method. The nature of the survey framework introduced a sampling bias: participants were caregivers with access to an Internet connection and knowledge about Internet browsing and a reading level of fifth grade or higher. At the start of the survey, caregivers without those characteristics were eliminated, skewing our sample toward a more affluent and educated population of caregivers. Internet access is far from universal in the participant countries, and the proportion of caregivers who could not participate in the study because they lacked Internet access ranged from 23\% (Chile) to 48.2\% (Uruguay; see Table 1(Internet Live Stats, 2015)). This sampling bias is also evident in the proportion of caregivers 
using only private insurance to cover services for their children with ASD (74.2\%). This is noteworthy because all the participant countries have universal health coverage (Table 1).

Overall, our results pinpoint the lack of health-related services encounters during the lifespan for a significant proportion of our sample (19\%), which is similar to the $15 \%$ reported by the SEAN study (Daniels et al., 2017). For their study, Daniels et al. (2017) surveyed a total of 758 caregivers from Albania, Bulgaria, Croatia, and Turkey on the characteristics of their children with ASD and on the topics of service encounters and caregiver perceptions. Interestingly, when exploring the total number of hours per week received in our sample, $37 \%$ reported zero hours per week. Such a discrepancy could be attributed to the number of participants receiving only medication or biomedical services. Those services were not included in the hours-per-week analysis.

It is widely considered that 40 hours per week is the optimal treatment dose for intervention in children with ASD (The Council of Autism Service Providers [CASP], 2020). However, there is no one-size-fits-all dosage for this issue (Kasari, 2015), and sociocultural barriers and low social determinants of health may contribute to intervention uptake, engagement, and efficacy (Pellecchia et al., 2019). Recent guidelines have suggested that the "dose" when working with limited behaviors in individuals with ASD is 10 to 25 hours per week and 30 to 40 hours per week if the treatment is across multiple behavioral domains (Pellechia et al., 2019; CASP, 2020). Considering those numbers, our sample is far below treatment standards: $37 \%$ are receiving zero hours per week, $55 \%$ are receiving between 1 and 10 hours, $5 \%$ between 11 and 20 , and only $3 \%$ above 20 . In addition, the number of hours per week decreases with age. This is a somber landscape if we factor in the sampling bias we described above-our sample is 
composed of affluent caregivers. If this is true, how would access to services look for the lowresource caregivers in these countries?

Neurologists were the medical professionals most frequently involved in the diagnostic process across all age groups, whereas pediatricians were the least involved. Mental health specialists are scarce in Latin American and Caribbean countries (WHO, 2017), which directly affects access to diagnosis and, therefore, early referral for services. Brazil is an exception, however; neurologists have higher availability in Brazil's health system, ranking as the second most available medical specialists in the country (Scheffer et al., 2018). Public expenditure on mental health is meager in LAMIC, and more than $80 \%$ of those funds go to mental hospitals, leaving few resources for outpatient mental health treatment ((World Health Organization, 2018), 2018). A dearth of trained professionals in LACC could be one of the main delaying factors for ASD diagnosis and delayed referral for treatment. Thus, training pediatricians and mental health specialists in responding to parental concerns is a priority for speeding ASD identification and early referral in LACC.

An analysis of the specific ASD services show ST as the most used service for all age groups in our sample, which is in line with reports of other LAMICs (Daniels et al., 2017); (Salomone et al., 2016). Although its use decreased with age, it was still frequently used for adolescents. The same trajectory was found for OT, whose use also decreased with age. That both ST and OT had been the most frequently used service encounters is noteworthy, although for the fewest number of hours per week among all types of services listed in the survey. Neither ST nor OT is specific for ASD or targets its core symptoms, but they are both standard services delivered in public institutions in most of the participant countries, making their use more frequent across countries and age groups. In contrast, use of BT appears to increase from 
preschool through adolescence. Significantly fewer adolescents receive ST, OT, or BT, which aligns with recent literature describing decreased use of services with age (Cidav et al., 2013; Shattuck et al., 2011; Turcotte et al., 2016).

The use of medication in individuals with ASD has been compared to medication use for schizophrenia or ADHD (Jobski et al., 2017), but the medication in ASD is used for non-core symptoms (i.e., irritability, aggression) (Fusar-Poli et al., 2019) and the psychiatric comorbidities (Buck et al., 2014). Despite the lack of efficacious pharmacological therapies available for ASD core symptoms at present, we found that $37 \%$ of our sample have received medication during their lifetime and that its use substantially increases with age. Different studies also found that medication use tends to increase with age (Buck et al., 2014; Gotham et al., 2015; Jobski et al., 2017).

Most children are enrolled in regular school, although their enrollment decreases with age. As educational systems become more inclusive, it is possible that younger children have more access to such inclusive practices than adolescents. However, support for children in regular school is not as common as standards suggest (National Research Council, 2001). For school-based services reported by caregivers, the proportion of individuals without services is even larger than for health services. As expected, preschool children receive fewer educational services than the older groups. For children aged 4 or younger, there is no expectation for school enrollment, so use of fewer services could also be related to the availability of educational services for this age group. Diagnosis of ASD usually occurs after the age of 5 (Montiel-Nava et al., 2017; Ribeiro et al., 2017; Zuckerman et al., 2014). Our sample had a mean age of diagnosis of 47 months; however, the difference across age group was significant, with a range of 32.8 months for preschool children to 73.1 months for adolescents. A delayed diagnosis of ASD has 
been associated with inadequate access to healthcare, which is an environmental risk for the delay in identification and access to services (Magana et al., 2013; Thomas et al., 2007;

Zwaigenbaum \& Penner, 2018). As we have mentioned, for most countries in this study, children with any disability must obtain a disability certificate before they are referred to any kind of educational services. Such a requirement delays and hinders access to timely services. More than half of the children in the school-age and adolescent groups were also without educational services, which aligns with other studies (Havlicek et al., 2016; Shattuck et al., 2011). As with health services, a shortage of special education schools and classrooms might be responsible for the high proportion of children and adolescents without educational services for ASD. A significant group of our participants were receiving in-class tutoring, which is not regularly covered by the school or insurance and requires caregivers to pay out of pocket. Because tutoring is a "private" service, an in-classroom tutor might be an option only for caregivers who are able to afford it.

Our study found no association between clinical and sociodemographic variables and the type of services used, or among the number of hours per week, which is also true for other studies (McIntyre \& Barton, 2010). Because this study used parents' reported data about the service encounters and hours per week, we cannot draw conclusions about the reasons for selecting and using each type of service. There may be factors not included in the survey that could shed light on the differences in the use of services, such as availability of services, costs, and cultural acceptance of the different services. Issues such as transportation, knowledge about the benefits of treatment, and severity of symptoms have also been connected to service access (Magana et al., 2013; Nowell et al., 2015) but were not surveyed in this study. 
The various limitations of this study must be considered in interpreting its results of this study must be interpreted considering its various limitations. First, caregiver information was provided without clinical confirmation. In countries with limited research and epidemiological resources, caregiver surveys provide a rich source of information on the demographic and clinical characteristics of individuals with ASD and their families (Lai \& Weiss, 2017; Narendorf et al., 2011; Shattuck et al., 2011; Zuckerman et al., 2017). Second, we used a sample of convenience that might have yielded a biased sample with most of our families coming from higher educational backgrounds, leaving out those who did not have access to the internet or were not part of a parent association. It has been suggested that the ability to afford services increases the odds of use of services for pre-school and school-age children (Lai \& Weiss, 2017). Along those lines, we could expect that our findings are underestimations of the use of services in the general population with ASD who might have lesser resources and limited or no access to services.

That a significant proportion of children and adolescents are not receiving ASD services indicates that this is an underserved population within both educational and health systems. Furthermore, policies and practices about services for ASD are inefficient because the services are not being used for an important part of the population in participant countries. Although participant countries have signed the CRPD (UnitedNations, 2006), results of this study indicate that the rights outlined in that agreement have not been fully realized for individuals with ASD and their families in Latin American countries. Thus, these data underscore the need for national education and health departments to look into schools and strengthen their services for children with ASD as well as enforce an inclusive curriculum (Valdez et al., 2017). 
This study identifies the frequency of service encounters and hours of services received per week related to the ages of individuals with ASD. ST, OT, and BT services decrease with patient age, whereas medication increases. The most commonly endorsed services are not specific to ASD and have low-to-moderate evidence of effectiveness but are widely available in public and private institutions; these services exist in outpatient mental health contexts. Most importantly, regardless of age group, a large proportion of individuals are not receiving treatment, and those receiving treatment get fewer hours than best practice recommendations specify. For adolescents, the gaps in treatment are even greater and less consistent because available services are scarce, aside from medication.

Despite the limitations, this study has significant implications. We address a gap in the existing research literature by both describing and comparing the use of services across age groups (including adolescents) and in reporting such data in a population of Latinos living in LAMICs. ASD as a diagnosis is relatively new for our countries, and governments are just beginning to develop ASD-specific programs. ASD is a disorder with increasingly high prevalence that should be a top public health agenda priority for any country. Failure to offer timely identification and intervention will result in more impairment of the individual and burden for the family. Although there are several initiatives to develop more resources for this population in LAAC, the provision of services for ASD is still undervalued. Furthermore, Furthermore, given that these programs decrease in availability for adolescents, it is clear that they are not being developed to meet the lifespan needs of individuals with ASD. Many such individuals might not be receiving the services they need, while most children are mainly receiving therapies with low-to-moderate evidence of effectiveness at a frequency below the recommended standards. Our findings indicate a need for further investigation of the role of 
demographic variables and availability of services in ensuring access to these services as well as factors related to use of services across different age groups. Analyses of the use of different services by age group could inform policymakers' resource allocation decisions and will help determine how best to deliver and finance both health care and educational care for children with ASD.

\section{References}

American Psychiatric Association, A. (2000). Diagnostic and statistical manual of mental disorders (4th ed., Text Revision). .

AmericanPsychiatricAssociation. (2013). Diagnostic and statistical manual of mental disorders (5th ed.). American Psychiatric Publishing.

Law 24901. Health services for people with disabilities (Discapacidad. Sistema de prestaciones basicas), (1997). http://servicios.infoleg.gob.ar/infolegInternet/verNorma.do?id=47677

Argentine Ministry of Health and Social Development, M. (2001). Law 25504 (Ley 25504). https://www.argentina.gob.ar/normativa/nacional/ley-24308-70726

Argentine Ministry of Health and Social Development, M. (2014). Law 27.043 (Ley 27.043). http://servicios.infoleg.gob.ar/infolegInternet/anexos/240000-244999/240452/norma.htm

Decree 777/2019 (Decreto 777/2019). Bylaws of Law No 27.043 (Reglamentación de la Ley N ${ }^{\circ}$ 27.043.), (2019).

https://www.boletinoficial.gob.ar/detalleAviso/primera/221428/20191120

Backes, B., Mônego, B. G., Bosa, C. A., \& Bandeira, D. R. (2014). Psychometric properties of assessment instruments for autism spectrum disorder: a systematic review of Brazilian studies. . Jornal Brasileiro de Psiquiatria, 63(2), 154-164. https://doi.org/ https://doi.org/10.1590/0047-2085000000020 
Bagaiolo, L. F., Mari, J. J., Bordini, D., Ribeiro, T. C., Martone, M. C. C., Caetano, S. C., Brunoni, D., Brentani, H., \& Paula, C. S. (2017, Jul). Procedures and compliance of a video modeling applied behavior analysis intervention for Brazilian parents of children with autism spectrum disorders. Autism, 21(5), 603-610. https://doi.org/10.1177/1362361316677718

Becker, M. M., Wagner, M. B., Bosa, C. A., Schmidt, C., Longo, D., Papaleo, C., \& Riesgo, R. S. (2012, Mar). Translation and validation of Autism Diagnostic Interview-Revised (ADI-R) for autism diagnosis in Brazil. Arq Neuropsiquiatr, 70(3), 185-190. https://doi.org/10.1590/s0004-282x2012000300006

Bordini, D., Paula, C. S., Cunha, G. R., Caetano, S. C., Bagaiolo, L. F., Ribeiro, T. C., Martone, M. C. C., Portolese, J., Moya, A. C., Brunoni, D., Bosa, C., Brentani, H., Cogo-Moreira, H., \& de Jesus Mari, J. (2020, Aug). A randomised clinical pilot trial to test the effectiveness of parent training with video modelling to improve functioning and symptoms in children with autism spectrum disorders and intellectual disability. $J$ Intellect Disabil Res, 64(8), 629-643. https://doi.org/10.1111/jir.12759

Linha de Cuidado na atenção a pessoa com Transtorno do Espectro Autista e suas famílias. , (2014b). http://bvsms.saude.gov.br/bvs/publicacoes/linha_cuidado_atencao pessoas transtorno.pd $\underline{\mathrm{f}}$

Diretrizes de Atenção à Reabilitação da Pessoacom Transtornos do Espectro do Autismo (TEA). (2014a). https://bvsms.saude.gov.br/bvs/publicacoes/diretrizes_atencao_reabilitacao_pessoa_autis $\underline{\text { mo.pdf }}$

Broder-Fingert, S., Shui, A., Pulcini, C. D., Kurowski, D., \& Perrin, J. M. (2013, Jul). Racial and ethnic differences in subspecialty service use by children with autism. Pediatrics, 132(1), 94-100. https://doi.org/10.1542/peds.2012-3886

Buck, T. R., Viskochil, J., Farley, M., Coon, H., McMahon, W. M., Morgan, J., \& Bilder, D. A. (2014, Dec). Psychiatric comorbidity and medication use in adults with autism spectrum disorder. J Autism Dev Disord, 44(12), 3063-3071. https://doi.org/10.1007/s10803-014$\underline{2170-2}$

Centers for Disease Control and Prevention, C. (2014). National Survey of Children with Special Health Care Needs. Retrieved 06/12/2020 from http://www.cdc.gov/nchs/slaits/cshen.htm 
Centers for Disease Control and Prevention, C. (2015). Services to Pathways to Diagnosis and Services. Retrieved 06/12/2020 from http://www.cdc.gov/nchs/slaits/spds.htm

Educación especial publica orientaciones para profesionales asistentes de la educación en el PIE., (n.d). https://especial.mineduc.cl/educacion-especial-publica-orientaciones-paraprofesionales-asistentes-de-la-educacion-en-el-pie/

Chilean Ministry of Health, M. (2011). Guía de práctica clínica de detección y diagnóstico oportuno de los Trastornos del Espectro Autista (TEA). . Senadiswww.senadis.gob.cl > descarga > documento

Cidav, Z., Lawer, L., Marcus, S. C., \& Mandell, D. S. (2013, Apr). Age-related variation in health service use and associated expenditures among children with autism. J Autism Dev Disord, 43(4), 924-931. https://doi.org/10.1007/s10803-012-1637-2

Coelho-Medeiros, M. E., Bronstein, J., Aedo, K., Pereira, J. A., Arrano, V., Perez, C. A., Valenzuela, P. M., Moore, R., Garrido, I., \& Bedregal, P. (2019, Oct). M-CHAT-R/F Validation as a screening tool for early detection in children with autism spectrum disorder. Rev Chil Pediatr, 90(5), 492-499. https://doi.org/10.32641/rchped.v90i5.703 (Validacion del M-CHAT-R/F como instrumento de tamizaje para deteccion precoz en ninos con trastorno del espectro autista.)

Cukier, S., Arduini, M, Barrios, N., Berman, J, Ferrea, M Grodberg, D. (2019, October 2019). The autism mental status exam. Validation of a spanish version in argentina International Meeting of Autism Research. Regional Meeting, Puerto Varas, Chile. https://cdn.ymaws.com/www.autisminsar.org/resource/resmgr/files/regional_meeting/chile_2019/abstract_and_program_book f.pdf

Daniels, A. M., Como, A., Herguner, S., Kostadinova, K., Stosic, J., \& Shih, A. (2017, Aug). Autism in Southeast Europe: A Survey of Caregivers of Children with Autism Spectrum Disorders. J Autism Dev Disord, 47(8), 2314-2325. https://doi.org/10.1007/s10803-017$\underline{3145-\mathrm{X}}$

Durkin, M. S., Elsabbagh, M., Barbaro, J., Gladstone, M., Happe, F., Hoekstra, R. A., Lee, L. C., Rattazzi, A., Stapel-Wax, J., Stone, W. L., Tager-Flusberg, H., Thurm, A., Tomlinson, M., \& Shih, A. (2015, Oct). Autism screening and diagnosis in low resource settings: Challenges and opportunities to enhance research and services worldwide. Autism Res, 8(5), 473-476. https://doi.org/10.1002/aur.1575

Elsabbagh, M., Bruno, R., Wan, M. W., Charman, T., Johnson, M. H., Green, J., \& Team, B. (2015, Feb). Infant neural sensitivity to dynamic eye gaze relates to quality of parent- 
infant interaction at 7-months in infants at risk for autism. J Autism Dev Disord, 45(2), 283-291. https://doi.org/10.1007/s10803-014-2192-9

Elsabbagh, M., Divan, G., Koh, Y. J., Kim, Y. S., Kauchali, S., Marcin, C., Montiel-Nava, C., Patel, V., Paula, C. S., Wang, C., Yasamy, M. T., \& Fombonne, E. (2012, Jun). Global prevalence of autism and other pervasive developmental disorders. Autism Res, 5(3), 160 179. https://doi.org/10.1002/aur.239

Fombonne, E. (2009, May). A wrinkle in time: from early signs to a diagnosis of autism. $J$ Am Acad Child Adolesc Psychiatry, 48(5), 463-464. https://doi.org/10.1097/CHI.0b013e31819e40c0

Fusar-Poli, L., Brondino, N., Rocchetti, M., Petrosino, B., Arillotta, D., Damiani, S., Provenzani, U., Petrosino, C., Aguglia, E., \& Politi, P. (2019, Jun). Prevalence and predictors of psychotropic medication use in adolescents and adults with autism spectrum disorder in Italy: A cross-sectional study. Psychiatry Res, 276, 203-209. https://doi.org/10.1016/j.psychres.2019.04.013

Galdino, M. P., Pegoraro, L. F. L., Saad, L. O., Grodberg, D., \& Celeri, E. (2020, Jul). Evidence of Validity of the Autism Mental Status Examination (AMSE) in a Brazilian Sample. $J$ Autism Dev Disord, 50(7), 2320-2325. https://doi.org/10.1007/s10803-018-3530-0

Gotham, K., Marvin, A. R., Taylor, J. L., Warren, Z., Anderson, C. M., Law, P. A., Law, J. K., \& Lipkin, P. H. (2015, Oct). Characterizing the daily life, needs, and priorities of adults with autism spectrum disorder from Interactive Autism Network data. Autism, 19(7), 794804. https://doi.org/10.1177/1362361315583818

Havlicek, J., Bilaver, L., \& Beldon, M. (2016, Jan). Barriers and facilitators of the transition to adulthood for foster youth with autism spectrum disorder: Perspectives of service providers in Illinois. Children and Youth Services Review, 60, 119-128. https://doi.org/10.1016/j.childyouth.2015.11.025

Hoffman, L., Marquis, J., Poston, D., Summers, J. A., \& Turnbull, A. (2006). Assessing family outcomes: Psychometric evaluation of the beach center family quality of life scale. . Journal of Marriage and Family, . 68(4), 1069-1083.

Howlin, P., Magiati, I., \& Charman, T. (2009, Jan). Systematic review of early intensive behavioral interventions for children with autism. Am J Intellect Dev Disabil, 114(1), 2341. https://doi.org/10.1352/2009.114:23;nd41

Interactive Autism Network (IAN), I. (2016). the Child with ASD Questionnaire, Version 2.0.3 https://iancommunity.org/cs/ian_research_questions/child_with_asd questionnaire

International Monetary Fund, T. (2020). Inflation rate, average consumer prices. Retrieved 06/15/2020 from https://www.imf.org/external/datamapper/PCPIPCH@,WEO/OEMDC 
Internet Live Stats, T. (2015). https://www.internetlivestats.com/internet-users-by-country/2015/

Jobski, K., Hofer, J., Hoffmann, F., \& Bachmann, C. (2017, Jan). Use of psychotropic drugs in patients with autism spectrum disorders: a systematic review. Acta Psychiatr Scand, 135(1), 8-28. https://doi.org/10.1111/acps.12644

Kasari, C. (2015, Apr). Update on behavioral interventions for autism and developmental disabilities. Curr Opin Neurol, 28(2), 124-129. https://doi.org/10.1097/WCO.0000000000000185

Kennedy-Hendricks, A., Epstein, A. J., Mandell, D. S., Candon, M. K., Marcus, S. C., Xie, M., \& Barry, C. L. (2018, Feb). Effects of State Autism Mandate Age Caps on Health Service Use and Spending Among Adolescents. J Am Acad Child Adolesc Psychiatry, 57(2), 125131. https://doi.org/10.1016/j.jaac.2017.10.019

Knapp, M., Romeo, R., \& Beecham, J. (2009, May). Economic cost of autism in the UK. Autism, 13(3), 317-336. https://doi.org/10.1177/1362361309104246

Lai, J. K. Y., \& Weiss, J. A. (2017, Aug). Priority service needs and receipt across the lifespan for individuals with autism spectrum disorder. Autism Res, 10(8), 1436-1447. https://doi.org/10.1002/aur.1786

Lindly, O. J., Zuckerman, K. E., \& Kuhlthau, K. A. (2019, Aug). Healthcare access and services use among US children with autism spectrum disorder. Autism, 23(6), 1419-1430. https://doi.org/10.1177/1362361318815237

Loomes, R., Hull, L., \& Mandy, W. P. L. (2017, Jun). What Is the Male-to-Female Ratio in Autism Spectrum Disorder? A Systematic Review and Meta-Analysis. J Am Acad Child Adolesc Psychiatry, 56(6), 466-474. https://doi.org/10.1016/j.jaac.2017.03.013

Magana, S., Lopez, K., Aguinaga, A., \& Morton, H. (2013, Jun). Access to diagnosis and treatment services among latino children with autism spectrum disorders. Intellect Dev Disabil, 51(3), 141-153. https://doi.org/10.1352/1934-9556-51.3.141

Mak, W., \& Cheung, R. (2008). Affiliate stigma among caregivers of people with intellectual disabilities or mental illness.

. Journal of Applied Research in Intellectual Disabilities, , 21(6), 532-545.

Mandell, D. S., Wiggins, L. D., Carpenter, L. A., Daniels, J., DiGuiseppi, C., Durkin, M. S., Giarelli, E., Morrier, M. J., Nicholas, J. S., Pinto-Martin, J. A., Shattuck, P. T., Thomas, K. C., Yeargin-Allsopp, M., \& Kirby, R. S. (2009, Mar). Racial/ethnic disparities in the identification of children with autism spectrum disorders. Am J Public Health, 99(3), 493-498. https://doi.org/10.2105/AJPH.2007.131243 
Mandy, W., Pellicano, L., St Pourcain, B., Skuse, D., \& Heron, J. (2018, Nov). The development of autistic social traits across childhood and adolescence in males and females. $J$ Child Psychol Psychiatry, 59(11), 1143-1151. https://doi.org/10.1111/jcpp.12913

Manzone, L. A. (2013). Adaptation and validation of the Modified CheCklist for AutisMin toddler for urban Argentina s population. Psicodebate, , 13, 79. https://doi.org/https://doi.org/10.18682/pd.v13i0.363

McIntyre, L. L., \& Barton, E. E. (2010). Early childhood autism services: How wide is the research to practice divide? Behavioral Development Bulletin, , 16(1), 34-43. . https://doi.org/http://dx.doi.org/10.1037/h0100518

Ministry of Health, C. (2011). Guía de práctica clínica de detección y diagnóstico oportuno de los Trastornos del Espectro Autista (TEA). . Senadiswww.senadis.gob.cl > descarga > documento

Moes, D. R., \& Frea, W. D. (2002, Dec). Contextualized behavioral support in early intervention for children with autism and their families. Journal of Autism and Developmental Disorders, 32(6), 519-533. https://doi.org/Doi 10.1023/A:1021298729297

Montiel-Nava, C., Chacin, J. A., \& Gonzalez-Avila, Z. (2017, Jul). Age of diagnosis of autism spectrum disorder in Latino children: The case of Venezuelan children. Autism, 21(5), 573-580. https://doi.org/10.1177/1362361317701267

Montiel-Nava, C., \& Pena, J. A. (2008, Mar). Epidemiological findings of pervasive developmental disorders in a Venezuelan study. Autism, 12(2), 191-202. https://doi.org/10.1177/1362361307086663

Narendorf, S. C., Shattuck, P. T., \& Sterzing, P. R. (2011, Aug). Mental health service use among adolescents with an autism spectrum disorder. Psychiatr Serv, 62(8), 975-978. https://doi.org/10.1176/ps.62.8.pss6208 0975

National Research Council, N. (2001). Educating Children with Autism. . T. N. A. Press.

Nightingale, S. (2012, Oct). Autism spectrum disorders. Nat Rev Drug Discov, 11(10), 745-746. https://doi.org/10.1038/nrd3771

Nowell, K. P., Brewton, C. M., Allain, E., \& Mire, S. S. (2015, Sep). The Influence of Demographic Factors on the Identification of Autism Spectrum Disorder: A Review and Call for Research. Review Journal of Autism and Developmental Disorders, 2(3), 300309. https://doi.org/10.1007/s40489-015-0053-X

Pacifico, M. C., de Paula, C. S., Namur, V. S., Lowenthal, R., Bosa, C. A., \& Teixeira, M. (2019). Preliminary evidence of the validity process of the Autism Diagnostic Observation Schedule (ADOS): translation, cross-cultural adaptation and semantic 
equivalence of the Brazilian Portuguese version. Trends Psychiatry Psychother, 41(3), 218-226. https://doi.org/10.1590/2237-6089-2018-0063

Padilla, J., Jager, J., Updegraff, K. A., McHale, S. M., \& Umana-Taylor, A. J. (2020, May). Mexican-origin family members' unique and shared family perspectives of familism values and their links with parent-youth relationship quality. Dev Psychol, 56(5), 9931008. https://doi.org/10.1037/dev0000913

Paula, C. S., Cunha, G. R., Bordini, D., Brunoni, D., Moya, A. C., Bosa, C. A., Mari, J. J., \& Cogo-Moreira, H. (2018, May). Identifying Autism with a Brief and Low-Cost Screening Instrument-OERA: Construct Validity, Invariance Testing, and Agreement Between Judges. J Autism Dev Disord, 48(5), 1780-1791. https://doi.org/10.1007/s10803-017$\underline{3440-6}$

Paula, C. S., Fombonne, E., Gadia, C., Tuchman, R., \& Rosanoff, M. (2011, Jan-Feb). Autism in Brazil: perspectives from science and society. Rev Assoc Med Bras (1992), 57(1), 2-5. https://www.ncbi.nlm.nih.gov/pubmed/21390445

Pejovic-Milovancevic, M., Stankovic, M., Mitkovic-Voncina, M., Rudic, N., Grujicic, R., Herrera, A. S., Stojanovic, A., Nedovic, B., Shih, A., Mandic-Maravic, V., \& Daniels, A. (2018, Sep). Perceptions on Support, Challenges and Needs among Parents of Children with Autism: the Serbian Experience. Psychiatr Danub, 30(Suppl 6), 354-364. https://www.ncbi.nlm.nih.gov/pubmed/30235173

Pellecchia, M., Iadarola, S., \& Stahmer, A. C. (2019). How meaningful is more? Considerations regarding intensity in early intensive behavioral intervention. . Autism, 23(5). https://doi.org/https://doi.org/10.1177/1362361319854844

Pereira, A., Riesgo, R. S., \& Wagner, M. B. (2008, Nov-Dec). Childhood autism: translation and validation of the Childhood Autism Rating Scale for use in Brazil. J Pediatr (Rio J), 84(6), 487-494. https://doi.org/10.2223/JPED.1828

Rast, J. E., Shattuck, P. T., Roux, A. M., Anderson, K. A., \& Kuo, A. (2018, Apr). The Medical Home and Health Care Transition for Youth With Autism. Pediatrics, 141(Suppl 4), S328-S334. https://doi.org/10.1542/peds.2016-4300J

Ribeiro, S. H., Paula, C. S., Bordini, D., Mari, J. J., \& Caetano, S. C. (2017, Oct-Dec). Barriers to early identification of autism in Brazil. Braz J Psychiatry, 39(4), 352-354. https://doi.org/10.1590/1516-4446-2016-2141

Rubin, L. I., Geller, R. J., Nodvin, J., Marcus, M., Howett, M., \& Merrick, J. (2011). Break the cycle of environmental health disparities in vulnerable children. Rev Environ Health, 26(3), 135-137. https://www.ncbi.nlm.nih.gov/pubmed/22206188

Salomone, E., Beranova, S., Bonnet-Brilhault, F., Briciet Lauritsen, M., Budisteanu, M., Buitelaar, J., Canal-Bedia, R., Felhosi, G., Fletcher-Watson, S., Freitag, C., Fuentes, J., 
Gallagher, L., Garcia Primo, P., Gliga, F., Gomot, M., Green, J., Heimann, M., Jonsdottir, S. L., Kaale, A., Kawa, R., Kylliainen, A., Lemcke, S., Markovska-Simoska, S., Marschik, P. B., McConachie, H., Moilanen, I., Muratori, F., Narzisi, A., Noterdaeme, M., Oliveira, G., Oosterling, I., Pijl, M., Pop-Jordanova, N., Poustka, L., Roeyers, H., Roge, B., Sinzig, J., Vicente, A., Warreyn, P., \& Charman, T. (2016, Feb). Use of early intervention for young children with autism spectrum disorder across Europe. Autism, 20(2), 233-249. https://doi.org/10.1177/1362361315577218

Scheffer, M. C., Cassenote, A. J. F., Guilloux, A. G. A., \& Dal Poz, M. R. (2018, May 2). Internal migration of physicians who graduated in Brazil between 1980 and 2014. Hum Resour Health, 16(1), 21. https://doi.org/10.1186/s12960-018-0286-8

Shattuck, P. T., Wagner, M., Narendorf, S., Sterzing, P., \& Hensley, M. (2011, Feb). Post-high school service use among young adults with an autism spectrum disorder. Arch Pediatr Adolesc Med, 165(2), 141-146. https://doi.org/10.1001/archpediatrics.2010.279

Soto, S., Linas, K., Jacobstein, D., Biel, M., Migdal, T., \& Anthony, B. J. (2015, Aug). A review of cultural adaptations of screening tools for autism spectrum disorders. Autism, 19(6), 646-661. https://doi.org/10.1177/1362361314541012

Stahmer, A. C., Schreibman, L., \& Cunningham, A. B. (2011, Mar 22). Toward a technology of treatment individualization for young children with autism spectrum disorders. Brain Res, 1380, 229-239. https://doi.org/10.1016/j.brainres.2010.09.043

Stewart, L. A., \& Lee, L. C. (2017, Jul). Screening for autism spectrum disorder in low- and middle-income countries: A systematic review. Autism, 21(5), 527-539. https://doi.org/10.1177/1362361316677025

The Council of Autism Service Providers (“CASP”), T. (2020). Applied Behavior Analysis Treatment of Autism Spectrum Disorder: Practice Guidelines for Healthcare Funders and Managers. Retrieved 06/06/2020 from https://casproviders.org/wpcontent/uploads/2020/03/ABA-ASD-Practice-Guidelines.pdf

Thomas, K. C., Morrissey, J. P., \& McLaurin, C. (2007, May). Use of autism-related services by families and children. J Autism Dev Disord, 37(5), 818-829. https://doi.org/10.1007/s10803-006-0208-9

Turcotte, P., Mathew, M., Shea, L. L., Brusilovskiy, E., \& Nonnemacher, S. L. (2016, Jul). Service Needs Across the Lifespan for Individuals with Autism. J Autism Dev Disord, 46(7), 2480-2489. https://doi.org/10.1007/s10803-016-2787-4

UNICEF. (2016). Health Equity Report 2916. Analysis of reproductive, maternal, newborn, child and adolescent health inequities in Latin America and the Caribbean to inform policymaking (978-92-806-4842-3). 
Convention on the rights of persons with disabilities. , (2006).

https://www.un.org/development/desa/disabilities/convention-on-the-rights-of-personswith-disabilities.html

Valdez, D., Gomez, L., \& Cuesta, J. L. (2017). Inclusive education and autism spectrum disorders: The working practice of support teachers in Argentina. Springer.

Varios, A. (2013). Declaracion de Santiago. Primera Conferencia Latinoamericana de Tratsorno del Espectro Autista. Revista Chilena de Psiquiatria Y Neurologia De La Infancia Y Adolescencia, 24(3), 164. http://www.saludinfantil.org/SubespecialidadesPediatricas/neurologia/Revista\%20SOPNI $\underline{\mathrm{A} \% 202013-2 . p d f}$

Vohra, R., Madhavan, S., Sambamoorthi, U., \& St Peter, C. (2014, Oct). Access to services, quality of care, and family impact for children with autism, other developmental disabilities, and other mental health conditions. Autism, 18(7), 815-826. https://doi.org/10.1177/1362361313512902

World Bank, T. (2015). The World Bank Annual Report 2015. http://hdl.handle.net/10986/22550

World Bank, T. (2017). World Bank Annual Report 2017 http://documents.worldbank.org/curated/en/143021506909711004/World-Bank-Annual$\underline{\text { Report-2017 }}$

World Health Organization, T. (2005). Mental Health ATLAS 2005. https://www.who.int/mental health/evidence/mhatlas $05 /$ en/

World Health Organization, T. (2017). Mental Health ATLAS 2017. https://www.who.int/mental_health/evidence/atlas/profiles-2017/en/

World Health Organization, T. (2018). Mental Health Atlas 2017. Country Profiles. . https://www.who.int/mental_health/evidence/atlas/profiles-2017/en/

Zuckerman, K. E., Friedman, N. D. B., Chavez, A. E., Shui, A. M., \& Kuhlthau, K. A. (2017, May). Parent-Reported Severity and Health/Educational Services Use Among US Children with Autism: Results from a National Survey. J Dev Behav Pediatr, 38(4), 260268. https://doi.org/10.1097/DBP.0000000000000437

Zuckerman, K. E., Sinche, B., Cobian, M., Cervantes, M., Mejia, A., Becker, T., \& Nicolaidis, C. (2014, Oct). Conceptualization of autism in the Latino community and its relationship 
with early diagnosis. $J$ Dev Behav Pediatr, 35(8), 522-532.

https://doi.org/10.1097/DBP.0000000000000091

Zwaigenbaum, L., \& Penner, M. (2018, May 21). Autism spectrum disorder: advances in diagnosis and evaluation. BMJ, 361, k1674. https://doi.org/10.1136/bmj.k1674 



\section{Table 1}

EXPENDITURE ON MENTAL HEALTH AND RELATED SERVICES BY COUNTRYa

\begin{tabular}{|c|c|c|c|c|c|c|c|c|c|}
\hline Country & $\begin{array}{l}\text { Income } \\
\text { Group }^{b}\end{array}$ & $\begin{array}{l}\text { MH Expenditure } \\
\text { per Person (\%) }\end{array}$ & $\begin{array}{c}\text { MH } \\
\text { Regulation }\end{array}$ & MH Financing & Psychiatrists $^{d}$ & Psychologists $^{d}$ & $\begin{array}{l}\text { Occupational } \\
\text { Therapists }^{d}\end{array}$ & $\begin{array}{c}\text { Speech } \\
\text { Therapists }^{d}\end{array}$ & $\begin{array}{l}\text { Internet } \\
\text { Access }^{\mathrm{e}}\end{array}$ \\
\hline Argentina & $\begin{array}{l}\text { Upper } \\
\text { Middle }\end{array}$ & NR & Yes & Fully insured & 18.62 & 222.57 & NR & NR & 69.2 \\
\hline Brazil & $\begin{array}{l}\text { Upper } \\
\text { Middle }\end{array}$ & 5.9 & $\begin{array}{l}\text { Partially } \\
\text { enforced }\end{array}$ & Fully insured & 3.16 & 12.38 & 2.86 & 3.76 & 66.4 \\
\hline Chile & High & 2.6 & $\begin{array}{l}\text { None } \\
\text { reported }\end{array}$ & Fully insured & 8.72 & NR & NR & NR & \\
\hline $\begin{array}{c}\text { Dominican } \\
\text { Republic }\end{array}$ & $\begin{array}{l}\text { Upper } \\
\text { Middle }\end{array}$ & 0.73 & Yes & & 2.35 & 7.60 & .54 & .15 & \\
\hline Uruguay & High & NR & $\begin{array}{c}\text { Person } \\
\text { pays at } \\
\text { least } 20 \% \\
\text { of mental } \\
\text { health } \\
\text { services }\end{array}$ & Fully insured & 16.75 & NR & NR & NR & \\
\hline Venezuela & $\begin{array}{l}\text { Upper } \\
\text { Middle }\end{array}$ & Not reported & $\begin{array}{c}\text { Not } \\
\text { reported }\end{array}$ & Fully insured & 24 & NR & NR & NR & \\
\hline $\begin{array}{l}\text { aWorld Hea } \\
\text { b World Ban } \\
\text { c United Nat } \\
\text { d per } 100.00 \\
\text { e Percentag }\end{array}$ & $\begin{array}{l}\text { h Organiz } \\
\text { (2015) } \\
\text { ons Estim } \\
\text { inhabita } \\
\text { of indivic }\end{array}$ & $\begin{array}{l}\text { ation (2017) } \\
\text { ates (2017) } \\
\text { its }\end{array}$ & in & ot homo & daving tung & 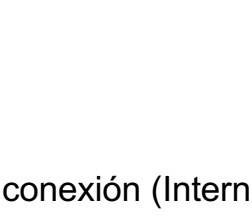 & . & & \\
\hline
\end{tabular}


Table 2:

Distribution of Demographic Characteristics of the sample

\begin{tabular}{|c|c|c|c|c|c|c|c|c|c|}
\hline \multirow{2}{*}{$\begin{array}{l}\text { Age Group/Characteristic }{ }^{a} \\
\text { Gender[ } \mathbf{N}(\%)]\end{array}$} & \multicolumn{2}{|c|}{$\begin{array}{l}\text { Pre School } \\
\mathrm{N}=1008\end{array}$} & \multicolumn{2}{|c|}{$\begin{array}{l}\text { Elementary School } \\
\mathrm{N}=1217\end{array}$} & \multicolumn{2}{|c|}{$\begin{array}{l}\text { Adolescents } \\
\mathrm{N}=295\end{array}$} & \multicolumn{2}{|c|}{$\begin{array}{c}\text { Total } \\
\mathrm{N}=2520\end{array}$} & \\
\hline & & & & & & & & & \\
\hline Male & 840 & $(83.3)$ & 1033 & $(84.9)$ & 250 & $(84.7)$ & 2123 & 84.2 & \\
\hline Female & 168 & (16.7) & 184 & (15.1) & 45 & (15.3) & 397 & 15.8 & \\
\hline Country $[\mathbf{N}(\%)]$ & & & & & & & & & *** \\
\hline Argentina & 273 & $(38.5)$ & 363 & $(51.2)$ & 73 & $(10.3)$ & 709 & 28.1 & \\
\hline Brazil & 484 & $(48.4)$ & 410 & $(41)$ & 106 & (10.6) & 1000 & 39.7 & \\
\hline Chile & 61 & $(24)$ & 142 & (55.9) & 51 & (20.1) & 254 & 10.1 & \\
\hline Dominican Republic & 55 & $(42.3)$ & 62 & $(47.7)$ & 13 & (10) & 130 & 5.2 & \\
\hline Uruguay & 115 & $(35.8)$ & 165 & (51.4) & 41 & (12.8) & 321 & 12.7 & \\
\hline Venezuela & 20 & (18.9) & 75 & (70.7) & 11 & (10.4) & 106 & 4.2 & \\
\hline Caregiver's Highest level of education[ $\mathbf{N}(\%)]$ & & & & & & & & & ** \\
\hline Elementary or less & 25 & $(2.5)$ & 42 & (3.4) & 6 & $(2.1)$ & 73 & 2.91 & \\
\hline High School Diploma & 153 & (15.3) & 218 & (18.0) & 39 & (13.2) & 410 & 16.32 & \\
\hline Undergraduate Degree & 586 & $(58.4)$ & 688 & $(56.6)$ & 191 & $(64.7)$ & 1465 & 58.32 & \\
\hline Graduate Degree & 237 & (23.6) & 262 & (21.6) & 59 & (20.0) & 558 & 22.21 & \\
\hline Insurance Coverage[ $\mathbf{N}(\%)]$ & & & & & & & & & ** \\
\hline Only Private & 731 & (74.9) & 856 & (73.1) & 216 & (76.3) & 1803 & 74.2 & \\
\hline Only Public & 170 & $(17.4)$ & 248 & (21.2) & 57 & (20.1) & 475 & 19.5 & \\
\hline Both Private and Public & 75 & $(7.7)$ & 67 & $(5.7)$ & 10 & (3.5) & 283 & 6.3 & \\
\hline Another Member with ASD & 95 & 3.8 & 162 & 6.4 & 27 & 1.1 & 284 & 11.3 & ** \\
\hline Current Diagnosis[ N (\%)] & $* * *$ & & & & & & & & \\
\hline Autism/Autistic Disorder & 171 & $(17.0)$ & 193 & (15.9) & 50 & $(16.9)$ & 414 & 16.4 & \\
\hline Asperger's Disorder & 56 & $(5.6)$ & 227 & (18.7) & 98 & (33.2) & 381 & 15.1 & \\
\hline PDD-NOS & 93 & (9.2) & 182 & (15.0) & 40 & (13.6) & 315 & 12.5 & \\
\hline PDD & 88 & $(8.7)$ & 110 & $(9.0)$ & 30 & $(10.2)$ & 228 & 9 & \\
\hline ASD & 600 & (59.5) & 505 & (41.5) & 77 & (26.1) & 1182 & 47 & \\
\hline Severity Index[N(\%)] & & & & & & & & & $* * *$ \\
\hline Low & 295 & $(29.2)$ & 213 & $(17.5)$ & 51 & (17.3) & 559 & $(22.2)$ & \\
\hline Medium & 510 & (50.7) & 474 & (38.9) & 105 & (35.6) & 1089 & $(43.2)$ & \\
\hline High & 203 & (20.1) & 530 & (43.6) & 139 & (47.3) & 872 & (34.6) & \\
\hline Age at diagnosis in months [mean $(S D)]$ & 32.8 & (10.5) & 50.9 & $(29.7)$ & 73.1 & $(47.1)$ & 46.3 & (29.9) & *** \\
\hline Professional involved in first diagnosis [ $N(\%)]$ & & & & & & & & & $* \star *$ \\
\hline Psychiatrist & 101 & $(10.1)$ & 213 & (17.7) & 65 & $(22.4)$ & 379 & 15.2 & \\
\hline
\end{tabular}


Interdisciplinary Team

Neurologists

Developmental pediatrician

Psychologist

Pediatrician

ancludes valid responses only, may not total 2520

${ }^{* * *} \mathrm{a} \leq .001,{ }^{* *} \mathrm{a} \leq .01,{ }^{*} \mathrm{a} \leq .05$

$\begin{aligned} 136 & (13.6) \\ 462 & (46.2) \\ 52 & (5.2) \\ 108 & (10.8) \\ 62 & (6.2)\end{aligned}$

$156 \quad(13.0)$

$484 \quad(40.2)$

$55 \quad(4.6)$

162 (13.5)

$62 \quad(5.2)$

$41 \quad(14.1)$

$121 \quad(41.7)$

$6 \quad(2.1)$

$27 \quad(9.3)$

$11(3.8)$

$\begin{array}{ll}333 & 13.4\end{array}$

$1067 \quad 42.8$

$\begin{array}{ll}113 & 4.5\end{array}$

$297 \quad 11.9$

$135 \quad 5.4$ 
Table 3:

Lifetime service encounters endorsed by caregivers of individuals with ASD by age group

\begin{tabular}{|c|c|c|c|c|c|c|c|c|c|}
\hline \multirow{2}{*}{$\begin{array}{l}\text { Age Group/Service Type }{ }^{a} \\
\text { Lifetime services [ } \mathbf{N}(\%)]\end{array}$} & \multicolumn{2}{|c|}{$\begin{array}{l}\text { Pre School } \\
\mathrm{N}=1008\end{array}$} & \multirow{2}{*}{\multicolumn{2}{|c|}{$\begin{array}{l}\text { Elementary School } \\
\mathrm{N}=1217\end{array}$}} & \multicolumn{2}{|c|}{$\begin{array}{c}\text { Adolescents } \\
\mathrm{N}=295\end{array}$} & \multicolumn{2}{|c|}{$\begin{array}{c}\text { Total } \\
\mathrm{N}=2520\end{array}$} & \\
\hline & & & & & & & & & \\
\hline Speech Therapy & 643 & $(65.1)$ & 745 & (62) & 172 & $(58.7)$ & 1626 & $(65.5)$ & ** \\
\hline Occupational Therapy & 440 & (44.7) & 501 & (42) & 132 & (45.7) & 1151 & $(46.6)$ & ** \\
\hline Behavior Therapy & 344 & $(35.5)$ & 518 & $(43.5)$ & 124 & $(42.5)$ & 989 & $(40.2)$ & ** \\
\hline Medication & 206 & $(21.4)$ & 548 & $(46.6)$ & 154 & $(53.3)$ & 908 & (37.3) & *** \\
\hline Physical Therapy & 254 & (26.2) & 397 & (33.8) & 103 & (54.3) & 754 & $(31.0)$ & *** \\
\hline Sensory Integration & 263 & $(27.1)$ & 341 & (28.9) & 84 & (29.0) & 688 & (28.2) & \\
\hline Cognitive Rehabilitation & 208 & (21.5) & 357 & $(30.3)$ & 107 & (36.9) & 672 & $(27.6)$ & *** \\
\hline Psychodynamic & 131 & $(13.6)$ & 226 & (19.3) & 75 & $(26.0)$ & 432 & $(17.8)$ & *** \\
\hline Biomedical & 129 & $(13.4)$ & 185 & $(15.8)$ & 42 & $(14.5)$ & 356 & $(14.7)$ & \\
\hline \multicolumn{10}{|c|}{ Number of Services Received (Lifetime) [ N (\%)] } \\
\hline None & 183 & $(18.3)$ & 232 & (19.2) & 54 & (18.4) & 469 & (18.7) & \\
\hline $1-3$ & 370 & (36.9) & 399 & (33) & 108 & (36.7) & 877 & (35) & \\
\hline $4-6$ & 335 & (33.5) & 411 & (34) & 97 & (33) & 844 & (33.7) & \\
\hline$>7$ & 113 & (11.3) & 167 & (13.9) & 35 & (11.9) & 315 & (12.6) & \\
\hline
\end{tabular}


Table 4

Current service encounters and number of hours per week received by age group

\begin{tabular}{|c|c|c|c|c|c|c|c|c|c|}
\hline \multirow{2}{*}{$\begin{array}{l}\text { Age Group/Service Type }^{a} \\
\text { Current Services [ N (\%)] }\end{array}$} & \multicolumn{2}{|c|}{$\begin{array}{l}\text { Pre School } \\
\mathrm{N}=1008\end{array}$} & \multicolumn{2}{|c|}{$\begin{array}{c}\text { Elementary } \\
\text { School } \\
N=1217\end{array}$} & \multicolumn{2}{|c|}{$\begin{array}{l}\text { Adolescents } \\
\qquad \mathrm{N}=295\end{array}$} & \multicolumn{2}{|c|}{$\begin{array}{c}\text { Total } \\
\mathrm{N}=2520\end{array}$} & \\
\hline & & & & & & & & & \\
\hline Speech Therapy & 596 & 60.8 & 554 & 46.7 & 69 & 24.0 & 1230 & 49.7 & *** \\
\hline Occupational Therapy & 382 & 39.4 & 370 & 31.5 & 62 & 21.5 & 814 & 33.5 & *** \\
\hline Behavior Therapy & 296 & 30.7 & 371 & 31.2 & 72 & 24.8 & 746 & 30.2 & \\
\hline Medication & 175 & 18.4 & 415 & 35.2 & 121 & 42.2 & 711 & 29.4 & *** \\
\hline Cognitive Rehabilitation & 157 & 16.5 & 250 & 10.4 & 54 & 18.9 & 467 & 19.2 & \\
\hline Physical Therapy & 188 & 7.8 & 216 & 18.5 & 37 & 12.8 & 446 & 18.4 & \\
\hline Sensory Integration & 202 & 21.2 & 189 & 16.1 & 28 & 9.7 & 419 & 17.4 & *** \\
\hline Psychodynamic & 89 & 3.7 & 155 & 13.3 & 50 & 17.5 & 295 & 12.2 & *** \\
\hline Biomedical & 87 & 9.2 & 95 & 8.2 & 20 & 7.0 & 204 & 8.4 & \\
\hline \multicolumn{10}{|l|}{$\begin{array}{l}\text { Number of Hours per week by service type } \\
\text { [x (SD)] }\end{array}$} \\
\hline Psychodynamic & 3.43 & 13.75 & 2.12 & 9.79 & 4.75 & 18.02 & 2.94 & 12.66 & \\
\hline Cognitive Therapy & 4.31 & 11.61 & 3.80 & 6.21 & 4.33 & 8.24 & 4.03 & 8.62 & \\
\hline Sensory Integration & 2.96 & 9.85 & 2.98 & 6.41 & 3.17 & 5.11 & 2.98 & 8.29 & \\
\hline Behavior Therapy & 4.39 & 8.99 & 4.26 & 6.48 & 5.07 & 8.98 & 4.39 & 7.83 & \\
\hline Physical Therapy & 2.97 & 10.54 & 2.06 & 3.53 & 2.12 & 1.98 & 2.48 & 7.53 & \\
\hline Occupational Therapy & 2.16 & 7.51 & 2.10 & 4.60 & 2.63 & 6.18 & 2.16 & 6.28 & \\
\hline Speech Therapy & 2.20 & 6.52 & 1.68 & 2.90 & 2.46 & 5.84 & 1.99 & 5.21 & \\
\hline \multicolumn{10}{|c|}{ Number of Total Hours of all services per week [N (\%)] } \\
\hline None & 323 & 32 & 465 & 38.2 & 151 & 51 & 939 & 37 & *** \\
\hline $1-5$ & 487 & 48.3 & 527 & 43.3 & 106 & 36 & 1120 & 45 & *** \\
\hline $6-10$ & 115 & 11.4 & 124 & 10.2 & 18 & 6.1 & 257 & 10 & *** \\
\hline $11-15$ & 37 & 3.7 & 33 & 2.7 & 4 & 1.4 & 74 & 3 & *** \\
\hline $16-20$ & 17 & 1.7 & 24 & 2 & 6 & 2 & 47 & 2 & *** \\
\hline$>20$ & 29 & 2.9 & 44 & 3.6 & 10 & 3.4 & 83 & 3 & \\
\hline Total Number of Hours per week [x (SD)] & 4.21 & 8.86 & 3.98 & 9.24 & 3.38 & 9.23 & 4 & 9.09 & *** \\
\hline
\end{tabular}

ancludes valid responses only; may not total 2520

${ }^{* * *} \mathrm{a} \leq .001,{ }^{* *} \mathrm{a} \leq .01,{ }^{*} \mathrm{a} \leq .05$. 
Table 5

Educational Placement of children with ASD by age group

\begin{tabular}{|c|c|c|c|c|c|c|c|c|c|}
\hline Age Group/Service Type ${ }^{a}$ & \multicolumn{2}{|c|}{$\begin{array}{l}\text { Pre School } \\
\mathrm{N}=1008\end{array}$} & \multicolumn{2}{|c|}{$\begin{array}{c}\text { Elementary } \\
\text { School } \\
\mathrm{N}=1217\end{array}$} & \multicolumn{2}{|c|}{$\begin{array}{l}\text { Adolescents } \\
\mathrm{N}=295\end{array}$} & \multicolumn{2}{|c|}{$\begin{array}{c}\text { Total } \\
\mathrm{N}=2520\end{array}$} & \\
\hline \multicolumn{10}{|c|}{ Current educational placement [ N (\%)] } \\
\hline Regular School & 745 & 85.7 & 814 & 75.2 & 160 & 60.9 & 1719 & 77.2 & $* \star \star$ \\
\hline Special Education School & 60 & 6.9 & 237 & 21.9 & 74 & 28.1 & 371 & 16.7 & $* * *$ \\
\hline Home Schooling & 3 & .3 & 5 & .5 & 3 & 1.1 & 11 & .5 & \\
\hline $\begin{array}{l}\text { Not enrolled in school } \\
\text { Academic Services at school }\end{array}$ & 62 & 7.1 & 26 & 2.4 & 26 & 9.9 & 125 & 5.6 & $* * *$ \\
\hline $\begin{array}{l}\text { Special Education Classroom for } \\
\text { children with disabilities }\end{array}$ & 29 & 4.3 & 81 & 8.8 & 18 & 7.6 & 265 & 13.6 & $* *$ \\
\hline $\begin{array}{l}\text { Special Education Classroom for } \\
\text { children with ASD }\end{array}$ & 37 & 5.6 & 91 & 9.9 & 19 & 8.1 & 147 & 7.5 & \\
\hline In-classroom Tutor & 139 & 20.8 & 236 & 25.4 & 39 & 16.6 & 414 & 21.1 & * \\
\hline No Educational Services & 462 & 69.3 & 519 & 55.9 & 159 & 67.6 & 1133 & 57.8 & * \\
\hline
\end{tabular}

${ }^{a}$ Includes valid responses only; may not total 2520

${ }^{* * *} \mathrm{a} \leq .001,{ }^{* *} \mathrm{a} \leq .01,{ }^{*} \mathrm{a} \leq .05$. 
Table 6

Factors associated with current number of hours of services received by individuals with ASD by age group

\begin{tabular}{lcccc}
\hline Age Group/Service Type $^{\mathrm{a}}$ & $\begin{array}{c}\text { Pre School } \\
\mathrm{N}=1008\end{array}$ & $\begin{array}{c}\text { Elementary School } \\
\mathrm{N}=1217\end{array}$ & $\begin{array}{c}\text { Adolescents } \\
\mathrm{N}=295\end{array}$ & \multicolumn{2}{c}{ Statistic } \\
\hline Socio-Demographic Factors & & & 17.3 & $x^{2}$ \\
Country & 33.23 & 25.98 & .11 & $x^{2}$ \\
Gender & 9.29 & .675 & -.081 & Spearman's $p$ \\
Caregiver's Highest level of education & -.008 & -.029 & .961 & $x^{2}$ \\
Another family member with ASD & 1.04 & 6.52 & 8.83 & $x^{2}$ \\
Insurance Type & 10.79 & 5.13 & & $x^{2}$ \\
Clinical Factors & & & 12.66 & Spearman's $p$ \\
Current Diagnosis & 27.41 & 15.20 & .078 & Spearman's $p$ \\
Age of Diagnosis & -.070 & .011 & -.029 & $x^{2}$ \\
Severity Index & .028 & .06 & 1.16 & $x^{2}$
\end{tabular}

